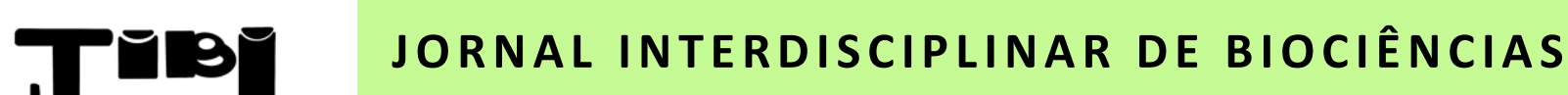

Homepage: http://www.ojs.ufpi.br/index.php/jibi

\section{Anatomy and arterial vascularization of female genital system of margay (Leopardus weidii, Schinz, 1821)}

\author{
Anatomia e vascularização arterial do sistema genital feminino do gato-maracajá (Leopardus \\ weidii, Schinz, 1821)
}

Andrezza Braga Soares da Silva ${ }^{1 *}$, Maria Michele Araújo de Sousa Cavalcante ${ }^{1}$, Ana Caroline Carvalho Santos ${ }^{1}$, Sérgio Paulo Lima Guerra ${ }^{1}$, Luana de Oliveira Lopes ${ }^{1}$, Dayseanny de Oliveira Bezerra $^{1}$, Aíla Alves Rocha Vieira ${ }^{1}$, Airton Mendes Conde Júnior ${ }^{1}$

${ }^{1}$ Department of Morphology, Health Sciences Center, Federal University of Piauí

\begin{abstract}
A B S T R A C T
We propose a descriptive study about female genital system and behavior of the arteries responsible for the blood supply to these organs in margay. It used one exemplary victim of poaching that to death. The animal was stored in freezer. Defrost at room temperature, it proceeded with the solution injection Neoprene Latex ' 650 ' colored in red for better identification of vessels before the adjacent structures. The specimen was fixed using an aqueous 10\% formaldehyde with subsequent immersion in the same fixative solution The female genital system of margay consists of a pair of ovaries, uterus with a pair of uterine horns, vagina and vulva. The arterial distribution of female system have a common vessel to iliac artery which branches and leads to internal pudendal artery sends a branch along the pudendal nerve pathway, urogenital artery. This, we performed divided into two branches, cranial and caudal. The cranial branch irrigates laterally cervix and uterine horns and caudal branch, vagina and vulva. The ovarian arteries, peers, originate from abdominal aorta only vascularizes the ovaries. The female genital system and vascularization of the genitals organs of margay resembles of domestic carnivores including cats and some wild felines like the ocelot and find differences with the same description held in other domestic and wild species.
\end{abstract}

KEYWORDS

Felines; Ovary; Uterus; Artery

RES U M O

Propõe-se um estudo descritivo acerca da anatomia do sistema genital feminino e o comportamento das artérias responsáveis pela irrigação sanguínea para estes órgãos no gato-maracajá (Leopardus wiedii). Foi utilizado um exemplar vítima da caça predatória e que veio a óbito. O animal foi armazenado em freezer, sob congelação. Descongelou-se em temperatura ambiente, procedeu-se com a injeção de solução Neoprene Látex ' 650 ' corado em vermelho para melhor identificação dos vasos perante as estruturas adjacentes. $\mathrm{O}$ espécime foi fixado utilizando solução aquosa de formaldeído a $10 \%$ com posterior submersão na mesma solução fixadora. O sistema genital feminino do gato-maracajá (L. wiedii) é composto por um par de ovários, útero com um par de tubas uterinas, vagina e vulva. A distribuição arterial dos órgãos genitais feminino têm como vaso comum a artéria ilíaca interna, a qual se ramifica e dá origem a artéria pudenda interna que emite um ramo ao longo do percurso do nervo pudendo, a artéria urogenital. Esta, apresentou-se dividida em dois ramos, cranial e caudal. O ramo cranial irriga lateralmente a cérvix e as tubas uterinas e o ramo caudal, a vagina e a vulva. As artérias ovarianas, pares, originam-se da aorta abdominal vascularizam unicamente os ovários. O sistema genital feminino e a vascularização dos órgãos genitais do gato maracajá (Leopardus wiedii) assemelha-se ao de carnívoros domésticos, inclusive o gato e alguns felídeos silvestres, como a jaguatirica e encontra diferenças com a mesma descrição realizada em outras espécies domésticas e silvestres.

PALAVRAS - CHAVE

Felídeos; Ovário; Útero; Artéria 


\section{INTRODUCTION}

Carnivorous mammals are characterized by to be at the top list of the Brazilian fauna predators performing an important ecological role in nature (VALENZUELAGALVAN et al., 2013; SEIBERT et al., 2015). Although small and hardly captured, some species of wild felines already included in the list of vulnerable animals to extinction, such as the Leopardus wiedii, popularly known as Margay, this in turn, has part of its population distribution threatened due the fragmentation of their habitat, poaching and pollution of the environment (MOREIRA et al., 2001; TORTATO et al., 2013).

The Margay belonging to the order Carnivora being widely distributed throughout Brazil, with the exception of Ceará and Rio Grande do Sul (OLIVEIRA et al., 2008, 2010; OLIVEIRA 2011). They are small animals with solitary and nocturnal behavior, feed on small mammals, birds and lizards (SEIBERT et al., 2015). Among the Brazilian felines, this species is the one with rather sharp arboreal habit, making it specialist in hunt birds and small arboreal rodents (OLIVEIRA; CASSARO, 2005; HODGE, 2012).

Although knowing both the respect of the ecological aspects and ethological of species, it weren't observed studies on the morphology and physiology. The Margay aren't used as an animal model for morphological research and little is known about clinical and epidemiological characteristics of the species. Thus, morphological studies of the organ systems of these animals are restricted. Since, in spite of being the most studied genital system, this has been restricted only to males system (MORAIS et al., 2002).

Overall, the genitals male and female, feature one pair of sex gonads and accessory organs to the system, which play roles hormone, of transport of substances, topographical among others (McENTEE, 2012). For the proper functioning of the system it's necessary an arterial network and richly vascularized vein to assure the survival of cells that participate of reproduction (CAMPOS; CULAU; ARAUJO, 2013).

In an attempt to contribute to the knowledge of the literature of these wild felines, this work aims to study the female genital system anatomy and behavior of the arteries responsible for the blood supply to organs of the female genital system of Margay (Leopardus wiedii) and, therefore, be a pioneer proposal for this purpose, since previous descriptions are not observed in this species of wild feline.

\section{MATERIAL AND METHODS}

For the present study, we used one example obtained by donation of IBAMA-PI victim of poaching and that death. Important to reiterate that wild animals are scarce and that research may not involve large numbers of specimens because many of these animals are endangered and therefore the remaining in ecosystems have important ecological role even more like this, that it is a feline predator who exercise control of several other species and keeps the faunal balance in the ecosystem in which it is inserted.

After receiving the donation term and confirm the species, the animal was forwarded to the Histotechnique and Embryology Laboratory, of the Department of Morphology of UFPI and stored in freezer under freezing.

Subsequent the thaw at room temperature (around 25 degrees centigrade), proceeded with cannulation of the dorsal aorta with Neoprene latex '650' solution (Du Pont do Brasil Indústrias Químicas) injection dyed by specific pigment in red color (Hidracor - Globo S/A Tintas e Pigmentos) for better identification of vessels at adjacent structures . Shortly after injection, there was a bandage in the dorsal aorta to prevent return of colored latex and the specimen was fixed by intramuscular, subcutaneous and intracavitary infusion using an aqueous $10 \%$ formaldehyde with subsequent immersion in the same fixative solution, for a minimum period of seven days.

Then the arteries connected to the female genital organs were dissected from an incision in the abdominal cavity at the level of the middle line from the xiphoid cartilage to the external genitalia. The organs were then dissected, labeled and identified arterial branches and photo documented using Digital Camera Sony DSC-H10 model. The nomenclature was based by International Committee on Veterinary Gross Anatomical Nomenclature (2012).

\section{RESULTS AND DISCUSSION}

The female genital system of Margay (L. wiedii) is composed of odd and even organs. Among the odds, we observed externally the vulva, comprising folds of tissue that demarcate the entrance to the vagina. The vagina, as well as other species is the joint region of the female genital system whit the urinary system, since it was observed that the external urethral ostium ends in the opening of the uterus.

The uterus of Margay, unique, tubular body extends cranially from vagina and cervix and has a named region cervix or body uterus forks into two cranial uterine horns, the left and the right. It is an elongated, tubular body that is limited to the uterine horns. The ovary, pair, has elongated oval appearance, relatively small and smooth surface. The anatomical description held for the female genitals of Margay resembles with the same in domestic 
cats and other felines has been studied (GETTY, 1986; ARANTES et al., 2014).

The arterial distribution of female genitals Margay (Leopardus wiedii) has a common vessel the internal iliac artery, vessel that comes from the abdominal aorta and follows a circuitous path toward the uterus and vagina. These findings agree with most domestic animals that have been studied by Getty (1986), except for birds, who have vaginal arteries as the main branch of the aorta. Moreover, in wild birds, like winged macaw (Aratinga leucophthalma) the external iliac artery also participates in the blood supply to the oviduct (PERES et al., 2014).
The internal iliac artery of margay it branches and gives rise to internal pudendal artery, it sends a branch along the pudendal nerve pathway, urogenital artery. In margay analyzed, the urogenital artery presented itself divided into two branches based on their location in cranial and caudal branch. The cranial branch emits vascular bundles forming lateral arcs that irrigating the cervix and uterine horns, being aided by caudal vesical artery. However, the caudal branch of urogenital artery emits beams be will caudally vascularized the reproductive system, especially the vagina and vulva (Figure 1).

The distribution of the urogenital artery branches into cranial and caudal presents similarities with domestic
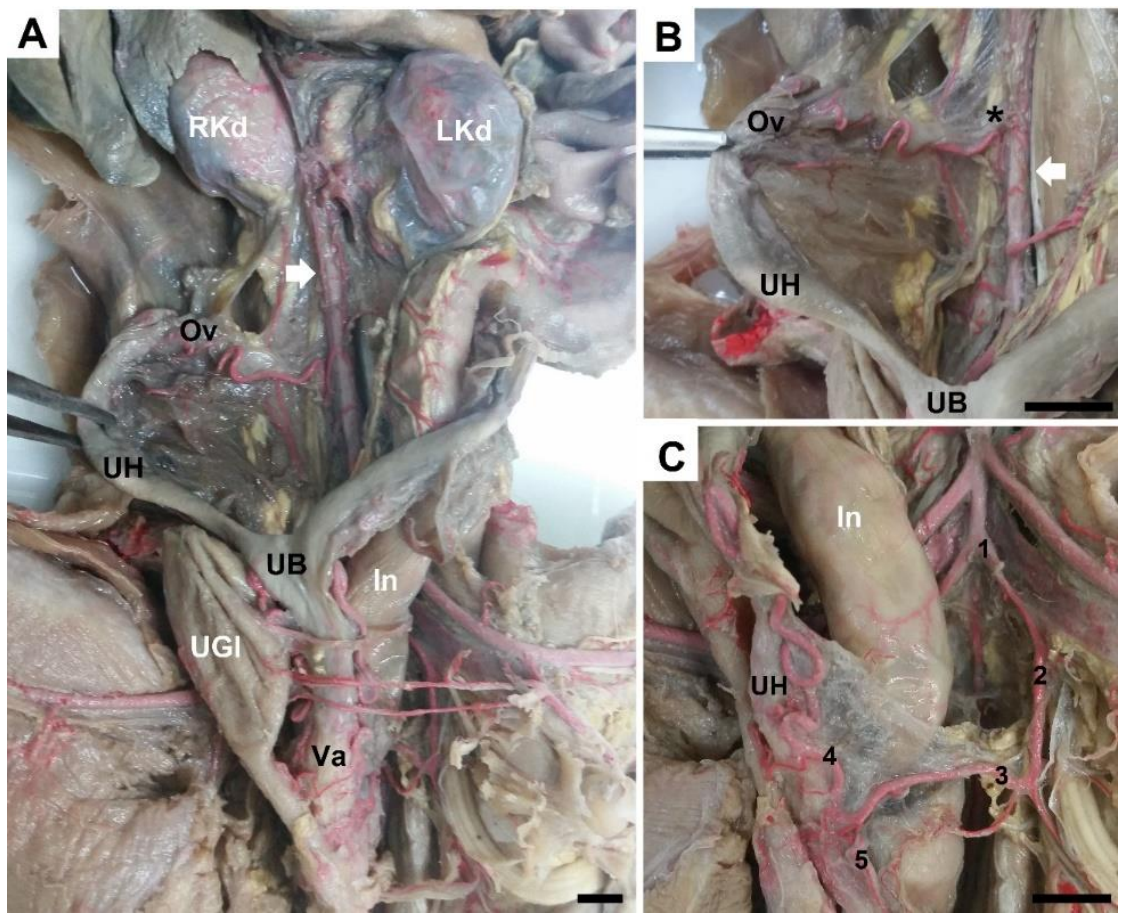

FIGURE 1. Photomicrograph of abdominal cavity of margay (Leopardus wiedii) showing the topography of the female genitals organs in relation to other (A) and the vascularization for Ovary (B) and Uterus / Vagina (C). Right Kidney (RKd), Left Kidney (LKd), Intestine (In), Urinary Glabber (UGl), Ovary (Ov), Uterine Horn (UH), Uterine Body (UB), Vagina (Va), abdominal aorta artery (white arrow), ovarian artery (asterisk), internal iliac artery (1), left pudendal artery (2), urogenital artery (3), Uterine branch of the urogenital artery (4) and vaginal branch of the urogenital artery (5). Bar: $1 \mathrm{~cm}$

carnivores, but inverse results in pigs where the cranial branch directs its supply to the vagina and the caudal branch to the uterus (GETTY, 1986; MIGLINO et al., 2001). In guinea pigs (Cavea porcellus) ovarian artery that perfusing the uterus, vagina and ovary, becomes the common vessel for the genital system of species and it have their origin in the abdominal aorta (PIRES, 2008).

The ovarian arteries, pairs, originate from the ventral portion of the abdominal aorta and are surrounded by ovarian plexus nerves. Similar in carnivores, already in domestic ruminants, the ovarian artery emits vascular bundles targeted for three structures: uterine horns, ovary and uterus (GETTY, 1986).

\section{CONCLUSION}

The female genital system and vascularization of the genitals of Margay (Leopardus wiedii) resembles that of domestic carnivores, including cats and some wild felines like the ocelot. However, there are differences with the same description provided in other domestic animals (horses, ruminants and poultry) and wild (maracana and guinea pigs), especially with respect to the terminal branches of the genitals. 


\section{REFERENCES}

ARANTES, R. C; HONORATO, A. G.; SOARES, M. J.; LIMA, A. K. F.; FERNANDES, B. M. Descrição do sistema genital feminino de jaguatirica (Leopardus pardalis). In: CONGRESSO BRASILEIRO DE VETERINÀRIA, 40, São Paulo, 2014 Resumos...São Paulo: Medicina Veterinária e Zootecnia. 2014. 80p.

CAMPOS, R.; CUlaU, O. V. C; ARAUJO, A. C. P. Vascularização arterial do estômago, duodeno, pâncreas, fígado e baço em Myocastor coypu (nutria). Acta Scientiae Veterinariae. v.41, n.1162, p.1-6, 2013.

GETTY, R.; SISSON, S.; GROSSMAN, J. D. Anatomia dos animais domésticos. 5. ed. Rio de Janeiro: Interamericana, 1986. v. 2, p. $1536-1538$.

HODGE, A. M. C. Methods of niche partitioning between ecuadorian carnivores and Habitat preference of the margay (Leopardus wiedii). North Carolina, 2012. 96p. Tese (Master of Science) - University of North Carolina Wilmington. 2012.

INTERNATIONAL COMMITTEE ON VETERINARY GROSS ANATOMICAL NOMENCLATURE. Nomina anatomica veterinaria. 5. ed. New York: Nomina Anatomica Veterinaria,, 2012. 198p.

McENTEE, K. Reprodutive pathology of domestic mammals. New York: Academic, 2012.

MIGLINO, M. A; SILVA, R. S.; MACHADO, R. F. Artérias destinadas ao útero e tuba uterina em gatas (Felis catus). Braz. J. vet. Res. anim. Sci., v. 38, n. 2, p. 55-61, 2001.

MORAIS, R. N; MUCCIOLO, R. G.; GOMES, M. L. F; LACERDA, O.; MORAES, W.; MOREIRA, N.; GRAHAM, L. H.; SWANSON, W.F.; BROWN, J. L. Seasonal analysis of semen characteristics, serum testosterone and fecal androgens in the ocelot (Leopardus pardalis), margay (L. wiedii) and tigrina (L.tigrinus). Theriogenology. v.57, p.2027-2041, 2002.

MOREIRA, N.; MONTEIRO-FILHO, E.L.A; MORAES, W.; SWANSON, W.F.; GRAHAM, L.H.; PASQUALI, O.L.; GOMES, M.L.F; MORAIS, R.N.; WILDT, D.E.; BROWN, J.L. Reproductive Steroid Hormones and Ovarian Activity in Felids of the Leopardus genus. Zoo Biol. v.20, p. 103-116, 2001.

OLIVEIRA, T. G.; CASSARO, K. Guia de campo dos felinos do Brasil. São Paulo: Sociedade de Zoológicos do Brasil. Fundação Parque do Zoológico de São Paulo. Pró-Vida Brasil. 2005.

OLIVEIRA, T. G. Ecologia e conservação de pequenos felinos no Brasil e suas implicações para o manejo. Belo Horizonte, 2011. 204 p. Tese (Doutorado em Ecologia, Conservação e Manejo da Vida Silvestre) - Universidade Federal de Minas Gerais. 2011.

OLIVEIRA, T.G.DE, KASPER, C.B., TORTATO, M.A., MARQUES, R.V., MAZIM, F.D., SOARES, J.B.G., SCHNEIDER, A., PINTO, P.T., PAULA, R.C.DE, CAVALCANTI, G.N., CAMPOS, C., QUIXABA-VIEIRA, O. Aspectos da ecologia e conservação de Leopardus tigrinus e outros felinos de pequeno-médio porte no Brasil, In: p. 37-105. In: OLIVEIRA, T.G.de, (Ed.), Estudos para o manejo de Leopardus tigrinus/Plano de ação para conservação de
Leopardus tigrinus no Brasil. Relatório final, Instituto PróCarnívoros/Fundo Nacional do Meio Ambiente, Atibaia, SP, Brasil, pp. 37-105. 2008.

OLIVEIRA, T. G.; TORTATO, M. A.; SILVEIRA, L.; KASPER, C. B.; MAZIM, F. D.; LUCHERINI, M.; JÁCOMO, A. T.; SOARES, J. B. G.; MARQUES, R. V.; SUNQUIST, M. E. Ocelot ecology and its effect on the small-felid guild in the lowland neotropics. In: MACDONALD, D. W.; LOVERIDGE, A. J. (eds.), Biology and conservation of the wild felids. New York: Oxford University, Oxford, 2010. p. 559-580.

PERES, N. V; DIA, S. G .L.; CRUZ, W. P.; LIMA, E. M. M.; MELO, A. O. F. Topografia e vascularização arterial do oviduto do maracanã (Aratinga leucophthalma, Müller, 1776). In: CONGRESSO DE INICIAÇÃO CIENTÍFICA, 26, São Paulo, 2014. Anais... São Paulo, 2014.

PIRES, M. A. B. Vascularização do útero: estudo morfológico e experimental. São Paulo, 2008.

SEIBERT, J .B.; MOREIRA, D. O.; MENDES, S. L.; GRATTI, A. Diet of two sympatric felids (Leopardus guttulus and Leopardus wiedii) in a remnant of Atlantic forest, in the montane region of Espírito Santo, southeastern Brazil. Bol. Mus. Biol. Mello Leitão. n.37, v.2, p.193-200. 2015.

TORTATO, M. A.; OLIVEIRA, T. G.; ALMEIDA, L. B.; BEISIEGEL, B. M. Avaliação do risco de extinção do gato maracajá Leopardus wiedii (Schinz, 1821) no Brasil. Biodiversidade Brasileira. v.3, n.1, p.78-83, 2013.

VALENZUELA-GALVAN, D.; LEON-IBARRA, A.; LAVALLE-SANCHEZ, A.; OROZCO-LUGO, L.; CHAVEZ, C. The Margay Leopardus wiedii and Bobcat Lynx rufus from the Dry Forests of Southern Morelos, Mexico. The Southwestern Naturalist, n.58, v.1, p.118-120, 2013. 